研究論文

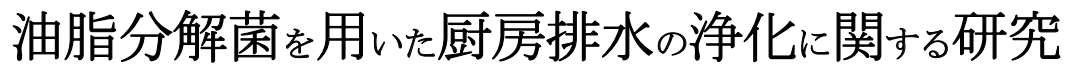

龍田典子*・横 堀加 奈 里*・井上 綾* 案浦謙二**手嶋 功**.上野大介* 井上興一*・染谷孝*

飲食店や食品工場の排水には，多量の油脂分が含まれていることがあり，下流側の下水管の閉塞防止や 下水道への污濁負荷低減を図るためにグリストラップの設置が義務づけられている，本研究では，グリス トラップから新規に油脂分解菌の分離を行い，311 株の分離細菌株から油脂分解能，タンパク質分解能お よびデンプン分解能の高い分離株 Aeromonas sp. KHU を選抜した. 本菌の培養および保存性に適した培地を 選定した結果，この培地中で安定した菌数を $30^{\circ} \mathrm{C} て ゙$ 約 5 週間維持できることを培養法および蛍光染色法に より確認した．本菌を厨房排水処理に適用する目的で，その油脂分解性を実験室で測定した結果，厨房排 水に含有する油脂分（n-ヘキサン抽出物）濃度の高低にかかわらず 15〜48 時間で 86〜 $91 \%$ の高い分解率 を示した（油脂分解速度 : 20 46 mg/l/hr)．さらに現場適用試験の結果， 300 l のグリストラップに本菌 を毎晚 $100 \mathrm{~m} l$ 接種することにより油脂分が 90\%以下にまで分解され，約 5 週間の試験期間中，油脂分濃 度を $40 \mathrm{mg} / \mathrm{l}$ 以下に維持した。

キーワード : 油脂分解菌, Aeromonas, グリストラップ, 厨房排水処理

\section{はじめに}

飲食店等の厨房排水には, 動植物油が含まれており, これが冷えて凝固すると下水管の閉塞を招くほか，終 末処理場の污濁負荷の一因となる。この問題を解消す るため, 下水道法第 12 条および建築基準法では, あら かじめ個々の発生源で事前に処理を行うことが必要で あるとし，グリストラップの設置を義務づけている.

グリストラップとは，㕌房から出る污水を受ける 200 程度の貯め桝であり, 構造としては, 㕑芥の受け カゴと, 油脂分(グリス)が浮き上がるように隔て板が 2 枚以上設けてあり，水面に油脂分の層ができるよう になっている．冷えて凝固した油脂分は，人手で清掃 回収され，産業廃棄物として焼却処分などの適切な処 分を行うことが必要である. トラップ内に蓄積された 油脂分は，定期的に除去される必要があり，その周期
は設計段階で定められており，一般には 7〜10 日であ る.また，トラップ内の受けカゴの影芥は，原則とし て毎日除去することが必要であり，長く放置しておく と厨芥の一部が腐敗して悪臭を放ち，非衛生的になる 恐れがある。

近年，グリストラップに曝気装置を設置し，同時に 微生物資材を使用し, 油脂分を好気的に分解浄化させ, グリストラップの清掃保守の負担を軽減させるバイオ 技術が出現し，その用途に用いる油脂分解菌に関する 論文もいくつか報告されている ${ }^{1-5)}$ 。これらでは，油 脂分解菌培養液の注入装置を現場に設置して，約 1 ケ 月間かけて毎日一定量接種する方式が主流である。こ の場合，微生物の油脂分解力と生存性の維持が品質管 理の上で特に重要となると考えられる。しかし我が国 では，微生物資材には品質管理の法的な制度や基準が なく，効果の疑わしいものも少なくない ${ }^{6)}$.

* 佐賀大学農学部 Noriko RYUDA, Kanari YOKOBORI, Aya INOUE, Kenji ANNOURA, Daisuke UENO, Koichi INOUE, Takashi SOMEYA

* * (株) 九州ケミカルクリーン Isao TESHIMA 
そこで本研究では, 厨房排水の浄化に有効な細菌を 得るため, 油脂分解能およびタンパク質分解能の強い 細菌をグリストラップ内の厨房排水から新規に分離・ 選抜し，培養および保存性に適した培地を検討した。 さらに，選択した油脂分解菌の菌種を同定し，厨房排 水中での油脂分解性を実験室試験および現場グリスト ラップ試験により検証した.

\section{1. 材料および方法}

\section{1 油脂分解菌の分離および性状試験}

\subsection{1 試 料}

九州各地の飲食店および旅館のグリストラップ 11 箇所より厨房排水を 11 点採取した（表 1 ).

\section{1 .2 分離培養}

滅菌生理食塩水を用いて, グリストラップ試料を $10^{4}$ $\sim 10^{5}$ 倍希釈し，その $100 \mu l$ を試料当たり 3 枚の普通 寒天培地（栄研化学: $5.0 \mathrm{~g} / \mathrm{l}$ 肉エキス, $10.0 \mathrm{~g} / \mathrm{l}$ ペ プトン, $5.0 \mathrm{~g} / \mathrm{l} \mathrm{NaCl}, 15.0 \mathrm{~g} / \mathrm{l}$ 寒天, pH7.0) に塗 抹接種し， $30^{\circ} \mathrm{C}$ で 7 日間培養した. 得られた細菌コロ ニーから試料当たり約 40 株を釣菌し画線塗抹分離法 により純粋培養を得た。

\subsection{3 有機物分解試験}

分離株の有機物分解能を寒天平板上で試験した。油 脂分解能試験には Tween20 培地 (10. 0 ml Tween20, 10.0 $\mathrm{g} /$ と ペプトン, $5.0 \mathrm{~g} /$ l $\mathrm{NaCl}, 0.1 \mathrm{~g} / \ell \mathrm{CaCl}_{2} \cdot 2 \mathrm{H}_{2} \mathrm{O}$,
$15.0 \mathrm{~g} / \mathrm{l}$ 寒天, pH7.4) を用い, 新鮮培養菌液を塗抹 接種し $30^{\circ} \mathrm{C}$ で 5 日間培養後, コロニーの周囲にみられ る Tween20 分解によるカルシウム塩の白濁帯をもつも のを油脂分解能陽性菌として判定した ${ }^{7)}$. タンパク質 分解能試験には，カゼイン培地 $(10.0 \mathrm{~g} / \mathrm{l}$ カゼインナ トリウム, $5.0 \mathrm{~g} / \mathrm{l} \mathrm{N}-Z$ Case Plus, $2.5 \mathrm{~g} /$ l 酵母エキ ス, $1.0 \mathrm{~g} / \ell$ グルコース, $0.88 \mathrm{~g} / \ell \mathrm{CaCl}_{2}, 4.4 \mathrm{~g} / \ell$ ク エン酸 3 ナトリウム, $15.0 \mathrm{~g} / \mathrm{l}$ 寒天，pH6,6）を用 い, $30^{\circ} \mathrm{C}$ で 2 日間培養後, カゼインの分解による白濁 帯をもつものをタンパク質分解能陽性菌として判定し $た^{8)}$.デンプン分解能試験には, デンプン培地 $(1.0 \mathrm{~g} / \ell$ 酵母エキス, $5.0 \mathrm{~g} / \mathrm{l}$ 可溶性デンプン, $15.0 \mathrm{~g} / \mathrm{l}$ 寒天, $\mathrm{pH}$ 無調整）を用い， $30^{\circ} \mathrm{C} て ゙ 3$ 日間培養した後，培地に ルゴール液（6.7 g/l ヨウ化カリウム， $3.3 \mathrm{~g} / \ell$ ヨー ド）を注ぎ，デンプン・ヨード反応により濃紫色とな った培地上で透明帯を示した株をデンプン分解能陽性 菌として判定した ${ }^{9)}$.

\subsection{4 病原因子試験}

病原因子試験として, DNA 培地（栄研化学： $500 \mathrm{~g} / \mathrm{l}$ ウシ心臟抽出液, $10.0 \mathrm{~g} / \ell$ ペプトン, $2.0 \mathrm{~g} / \ell$ デオキ シリボ核酸， $5.0 \mathrm{~g} / \mathrm{l} \mathrm{NaCl} ， 0.45 \mathrm{~g} / \mathrm{l} \mathrm{CaCl} ， 15.0 \mathrm{~g} / \mathrm{l}$ 寒天，pH7.4）を用いて核酸分解酵素産生の有無を，羊 血液寒天培地（栄研化学）を用いて溶血毒素産生の有

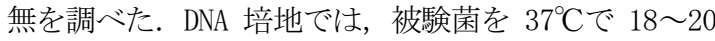
時間培養し，培地表面に $1.5 \mathrm{~N}$ の塩酸を約 $5 \mathrm{ml}$ かけて

表 1 厨房排水試料の細菌数および分離菌株の油脂分解能およびタンパク質分解能

\begin{tabular}{|c|c|c|c|c|c|c|c|c|}
\hline \multirow{2}{*}{$\begin{array}{l}\text { 試料 } \\
\text { 番号 }\end{array}$} & \multirow{2}{*}{ 採取場所 } & \multirow{2}{*}{$\mathrm{pH}$} & \multirow{2}{*}{$\begin{array}{l}\text { 培盖可能 } \\
\text { 細菌数 } \\
(\mathrm{CFU} / \mathrm{m} \ell) *\end{array}$} & \multirow{2}{*}{$\begin{array}{l}\text { 分離 } \\
\text { 株数 }\end{array}$} & \multicolumn{4}{|c|}{ 分離株に占める割合 (\%) } \\
\hline & & & & & グラム陰性菌 & 油脂分解菌 & 蛋白質分解菌 & 油脂十蛋白質 \\
\hline 1 & レストラン R & 9.0 & ND & 0 & NT & NT & NT & NT \\
\hline 2 & レストランP & 6.1 & $2.5 \times 10^{7}$ & 39 & 100 & 67 & 74 & 13 \\
\hline 3 & うどん店 S & 4.8 & $3.6 \times 10^{5}$ & 38 & 89 & 24 & 97 & 26 \\
\hline 4 & 旅館 K & 6.6 & 4. $7 \times 10^{7}$ & 38 & 97 & 39 & 92 & 32 \\
\hline 5 & レストランP & 6.4 & $1.1 \times 10^{7}$ & 40 & 90 & 25 & 100 & 28 \\
\hline 6 & レストラン T & 6.8 & $7.8 \times 10^{5}$ & 39 & 100 & 59 & 44 & 21 \\
\hline 7 & ラーメン店 K & 測定不可 & $3.3 \times 10^{6}$ & 0 & NT & NT & NT & NT \\
\hline 8 & 飲食街D & 4.7 & 1. $7 \times 10^{7}$ & 40 & 100 & 23 & 78 & 20 \\
\hline 9 & 旅館 A & 5.7 & $8.0 \times 10^{6}$ & 0 & NT & NT & NT & NT \\
\hline 10 & 旅館 B & 5.8 & $1.9 \times 10^{8}$ & 40 & 65 & 28 & 93 & 30 \\
\hline 11 & レストラン B & 4.5 & $5.2 \times 10^{8}$ & 37 & 81 & 27 & 89 & 30 \\
\hline 計 & & & & 311 & 90 & 36 & 83 & 29 \\
\hline
\end{tabular}

* 普通寒天培地

$\mathrm{ND}$ : Not detected（検出限界：30 CFU/m ）, NT : Not tested 
15 分以内にコロニーの周囲にDNA の分解による透明帯 が形成されたものを陽生と判定した. 羊血寒天培地で

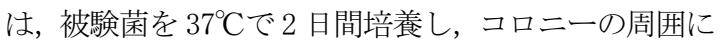
接して境界が明瞭で無色透明な溶血環が観察されたも のを $\beta$ 型溶血，コロニーの周囲に狭い緑色の溶血環が 観察されたものを $\alpha$ 型溶血, 溶血が全く認められない ものを $\gamma$ 型溶血（非溶血）と判定した.

\section{2 分離株の同定}

\section{1. $2.1 \mathrm{AP} \mathrm{I}$}

分離株の新鮮培養液を簡易同定キット API20NE（日

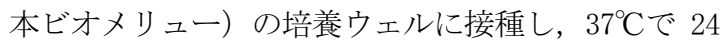
時間好気培養した。培養ウェル中の自発的な反応およ び試薬添加による呈色反応を記録し, その結果を 7 桁 の API プロファイルコードに変換し，これを API20NE プロファイルインデックスと照らし合わせて菌種を同 定した.

\section{2.2 シークェンシング}

分離株の $16 \mathrm{~S}$ rRNA の塩基配列を決定し, 菌種を同定 した。新鮮培養菌液から DNA を抽出し ${ }^{10)}, 10 \mathrm{~F}$ （ 5’-AGTTTGATCCTGGCTCAG-3'） および 1510R (5’-GGCTACCTTGTTACGACTT-3’ ) プライマーを用いて

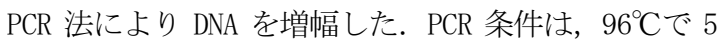
分間のホットスタート後, $96^{\circ} \mathrm{C}$ で 30 秒間の変成, $60^{\circ} \mathrm{C}$ で 1 分間のアニーリング, $72^{\circ} \mathrm{C}$ で 1 分間の伸長を 25 サイクル行った. PCR 産物を $1 \%$ アガロースゲルでの電 気泳動（100V, 20min） 後, エチジウムブロマイド染色 し,バンドを切り出した.QIAEX II （QIAGEN）で精製し， DNA 解析システム ${ }^{10)}$ を用いて塩基配列を決定した. 得 られた塩基配列データの編集には GENETYX-MAC(ゼネ ティックス)を使用し,データベース検索には DNA Data Bank of Japan（DDBJ）のBLAST を利用した.

\section{3 培養液の保存性試験}

分離株の液体培養に適した培地の検討および培養液 中における生存性を培養法および蛍光染色法を用いて 検証した.

\subsection{1 液体培地の検討}

PYG 培地 $(10.0 \mathrm{~g} / \mathrm{l}$ ペプトン, $5.0 \mathrm{~g} / \mathrm{l}$ 酵母エキス, $10.0 \mathrm{~g} / \ell$ グルコース, $1.0 \mathrm{~g} / \ell \mathrm{KH}_{2} \mathrm{PO}_{4}, 0.5 \mathrm{~g} / \ell \mathrm{MgSO}_{4}$ • $\left.7 \mathrm{H}_{2} 0,1.0 \mathrm{~g} / \mathrm{l} \mathrm{NaCl}, \mathrm{pH} 7.0\right)$ および $\mathrm{PY}$ 培地 $(10.0 \mathrm{~g} / \mathrm{l}$ ぺ プトン, $5.0 \mathrm{~g} / \mathrm{l}$ 酵母エキス, $1.0 \mathrm{~g} / \mathrm{l} \mathrm{KH}_{2} \mathrm{PO}_{4}, 0.5 \mathrm{~g} / \mathrm{l}$ $\left.\mathrm{MgSO}_{4} \cdot 7 \mathrm{H}_{2} \mathrm{O}, 1.0 \mathrm{~g} / \mathrm{l} \mathrm{NaCl}, \mathrm{pH} 7.0\right)$ それぞれとそれら を 2 倍および 5 倍希釈した液体培地を用いて被験菌の 培養性・保存性を検討した。 これらの培地 $18 \mathrm{ml}$ を入
れた L 字管に被験菌の新鮮培養液（普通ブイヨンで $30^{\circ} \mathrm{C}, 18$ 時間振とう培養したもの: 普通ブイヨンは普 通寒天培地から寒天を除いた培地） $180 \mu l$ を接種し， $30^{\circ} \mathrm{C}$ で 24 時間振とう培養した後，そのまま $30^{\circ} \mathrm{Cで} 42$ 日間静置培養し，普通寒天培地を用いた平板培養法に より経時的に菌数を測定した.

\subsection{2 液体培養の保存性試験}

5 倍希釈 PY 培地 $1,800 \mathrm{~m} \ell$ を 2 l容のポリプロピレ ン製ボトルに入れ，滅菌した。被験菌の新鮮培養液を この培地に $2 \mathrm{~m}$ 接種し, $30^{\circ} \mathrm{C}$ で 2 日間静置培養した後, そのまま $30^{\circ} \mathrm{Cで} 1$ ヶ月間静置保存した. 経時的に菌液 を $1 \mathrm{~m}$ 採取し, 普通寒天培地を用いた平板培養法 $\left(30^{\circ} \mathrm{C}\right.$, 2 日間）およびCTC-SYBR Green I 二重蛍光染色法によ り菌数を測定した.

\section{3. 3 CTC-SYBR Green I 二重蛍光染色法}

5-cyano-2, 3-ditolyl tetrazolium Chrolide (CTC) 法 ${ }^{11)}$ により, 被験菌の生細胞数を定量した。本法は, 呼吸活性を有する細胞を蛍光顕微鏡下で検出すること により生細胞を検出・定量する方法である. CTC は蛍 光を持たないが，菌体内に取り込まれた後，電子伝達 系の働きにより還元されて蛍光性で不溶性の CTC-formazan に変わり, 細胞内に沈着する. これに青 色 (B) 励起光を照射すると, オレンジ色の蛍光を発する. ただし，CTC-formazan 粒子は，1 細胞中に数個存在す ることがあり，また，細胞外に CTC-formazan 粒子が観 察されることもある. そこでSYBR Green I で細胞全体 を染め, 細胞内に CTC-formazan を持つものを計数する Yoshida \& Hiraishi (2004)の方法 ${ }^{11)}$ に従った.

被験菌液試料を除菌滅菌生理食塩水を用いて 3 回遠 心洗浄し（14,000 rpm, 5min），除菌滅菌生理食塩水 1 $\mathrm{m} \ell$ に再䀣濁した. マイクロチューブに除菌水 $400 \mu$ l, 基質液 $(5,000 \mathrm{mg} / \mathrm{l}$ 酵母エキス) $50 \mu$ l, $10 \mathrm{~g} / \mathrm{l}$ CTC 溶 液 $50 \mu \mathrm{l}, 10 \mathrm{mu}$ メルドラスブルー（電子伝達補助剤） $5 \mu$ lおよび培養液試料 $500 \mu$ lを入れ，よく混合し， $30^{\circ} \mathrm{C}$ で 4 時間インキュベートし, ホルマリン固定液(ホ ルマリン原液に $30 \mathrm{~g} / \mathrm{l}$ ホウ酸ナトリウム溶液を加え て中性にしたもの）を $20 \mu$ l添加し固定した．吸引濾 過器にメンブランフィルター（孔径 $5 \mu \mathrm{m}$ ) とヌクレ ポアフィルター（孔径 $0.2 \mu \mathrm{m} ）$ を順にのせ，その上 にファンネルをセットした. ヌクレポアフィルターは, あらかじめ, Poly-L-1ysine $(100 \mu \mathrm{g} / \mathrm{ml})$ 水溶液に一晚 浸し，親水化処理したものを使用した。フフンネルに 除菌水を約 $2 \mathrm{~m} \ell$ 程度入れてから, 試料を適量添加し, 
吸引濾過した. 除菌水数 $\mathrm{m} \ell$ により余剰染色液を洗浄し, 再度吸引濾過した。これに，0.1 M Phosphate buffer(pH7.2) を用いて 2,000 倍に希釈した SYBR Green（SG）I 溶液を約 $1 \mathrm{~m} \ell$ のせ, 室温, 遮光状態で 3 分間対比染色した。吸引濾過して染色液を取り除き, スライドグラスにイマージョンオイル (0lympus 製, 非蛍光，屈折率 1.516）を 1 滴落とし，そこに上記又 クレポアフィルターをのせ，その上にイマージョンオ イルを 1 滴のせて, カバーグラスで封入し, 落射型蛍 光顕微鏡（Nikon Optiphoto EFD-3）のB励起下（450 $\sim 490 \mathrm{n} \mathrm{m}$ ), 対物 100 倍で検鏡した. 黄緑〜緑色の蛍 光を発する細胞内に, 赤色〜橙色の CTC-formazan 粒子 が観察される細胞を生菌として計数した.

\section{4 油脂分解試験}

\section{4.1 サラダ油培地による油脂分解試験}

普通ブイヨンに市販のサラダ油（神戸物産 MK6, 原 材料; なたね油，大豆油）を $5 \mathrm{ml} / \mathrm{l}$ 添加したものをサ ラダ油培地（pH 7.0 0 0.2）として用いた. この培地 $100 \mathrm{ml}$ を $200 \mathrm{~m} l$ 容三角フラスコに入れ, シリコ栓を 付けてオートクレーブ滅菌した.

普通ブイヨンによる被験菌の新鮮培養液 $1 \mathrm{~m} \ell$ をサラ ダ油培地 $100 \mathrm{~m} \ell, 3$ 本にそれぞれ接種した. $30^{\circ} \mathrm{C}, 120$ $\mathrm{rpm}$ で 48 時間振とう培養し（レシプローカル振とう培 養機:Thomas, AT-12R), 経時的に 1 本ずつ取り出して, n一へキサン抽出物定量法（JIS K 0102）にて油脂分濃 度を測定し, 生菌数を普通寒天培地による希釈平板法 にて測定した。

\subsection{2 厨房排水による油脂分解試験}

中華料理店（愛媛県松山市）および佐賀大学学生食 堂の厨房排水を油脂分解試験に供した。厨房排水には 固形物や固形状の油脂分が含まれ, そのままでは測定 誤差が大きくなるため, ガラス䋊維濾紙（孔径 $1 \mu \mathrm{m}$ ) を用いて濾過し，固形物を除去したのち，ホモジナイ ザー（日本精機 AM-11 型）を用いて 15,000 rpm, 15 分間の分散処理を行い, 油脂分をエマルジョン化した. この処理液を分液漏斗（1 l容）に入れて約 10 分間静 置した後, 乳化した溶液のみを分取し, $1 \mathrm{M} \mathrm{NaOH} を$ 用 いてpH7.0〜7.3 に調整した.

上記前処理した厨房排水を 2 l容の三角フラスコ 2 個に 1 もずつ入れ，1個は無接種で，1個には被験菌株 の新鮮培養液を $1 \mathrm{~m}$ 接種し, いずれも $30^{\circ} \mathrm{C}$ で通気培養 し(通気量 $1.5 \mathrm{l} / \mathrm{min}$ ), 経時的に試料 $100 \mathrm{~m} \ell$ を採取し, 油脂濃度を測定した。

\section{5 グリストラップヘの接種試験}

佐賀大学学生食堂のグリストラップ (実容積 300 l) を用いて実地試験を行った。この食堂では平日約 1, 000 食を提供し, 1 日約 $8 \mathrm{~m}^{3}$ の厨房排水があった. グリストラップに曝気装置とタイマー付ペリスタポン プによる自動接種装置 (オイルコントロールシステム) を設置し，最初の 37 日間は曝気処理 $(5 \mathrm{l} / \mathrm{min})$ のみ とし, その後, 被験菌を毎晚 21 時に $100 \mathrm{~m} \ell$ 接種し, これを 35 日間続けた. 経時的に試料を採取し, 油脂分 濃度および $\mathrm{pH}$ (ガラス電極法) を測定した. なおサン プリングは学生食堂が営業する直前の午前 9 時に行っ た.

\section{2. 実験結果および考察}

\section{1 油脂分解菌の分離および同定}

九州各地の飲食店および旅館のグリストラップ 11 箇所から 11 点の厨房排水を採取した（表 1）。これら の試料の $\mathrm{pH}$ は 4.5 9.0 で, 普通寒天培地による培養 可能な細菌数は不検出ないし $10^{5} \sim 10^{8} \mathrm{CFU} / \mathrm{ml}$ であっ た.このうち試料 1 では菌数が不検出で $\mathrm{pH}$ が 9.0 であ ったことから，アルカリ性漂白殺菌剤が高濃度に使用 されたため,一時的に無菌状態になったものと考えら れた．また試料 7 では，グリストラップがラード分で 満たされ, $\mathrm{pH}$ 測定が不可能であった. 細菌数が比較的 高い試料8点から細菌株を分離純化し, 311 株を得て, それらをグラム染色および各種有機物分解試験に供し た（表 1). 分離株の $90 \%$ はグラム陰性菌で, 油脂分解 能およびタンパク質分解能を有する株はそれぞれ $36 \%$ よび $83 \%$ で, 油脂およびタンパク質分解の両方 をあわせ持つ株は $29 \%$ であった。

上記の結果から，㕌房排水中の細菌は，その生育環 境を反映して有機物分解能を有する細菌が多いことが 判明した. グリストラップ内は富栄養環境であるとと もに，消毒剤などの影響も大きく，極端な環境変動が みられる微生物生態系であるといえる。

得られた 311 株の分離菌株から, 油脂分解能に加え てタンパク質分解能およびデンプン分解能の高い 3 株 （KY8-27, KHU, KY5-1）を選抜し,API を用いて同定し， 同時に，病原因子について試験した。これら 3 菌株は いずれもグラム陰性無芽胞桿菌で，KY8-27 株は Rahnella aquatilis (同定確率 79.4\%)，KHU 株は Aeromonas hydrophila (94.0\%) および KY5-1 株は Serratia marcescens (99.6\%) と同定された. 病原因 
子の確認試験の結果, これら 3 菌株のうち, KY5-1 株の みが核酸分解酵素を有しており, S. marcescens の一般 的な性状と一致した。 また, 溶血性はいずれの菌株に も認められなかった. R. aquatilis は腸内細菌科に属 しており，病原的意義は不明なものが多いとされる ${ }^{12}$. 一方, KHU 株については, 核酸分解酵素および溶血性 いずれも陰性であり,インドール産生能, アセトインお よび硫化水素産生性などいくつかの項目で, A. hydrophila との相違が確認された（表 2).さらに, 16SrDNA における約 1, 500 塩基のシークエンシングに より, Aeromonas 属細菌と 99\%の確率で一致した.

これらの結果から，KY5-1 株は，病原因子を有する S. marcescens であり, 現場での使用には適さないと判 断した. KHU 株は Aeromonas 属の非病原性細菌と判断 され, 各種有機物分解能も高いことから, 油脂分解菌 の最良株として選定した。

\section{2 Aeromonas sp. KHU 株の保存性}

微生物を用いたグリストラップ内の油脂分解システ ムでは, 油脂分解菌の培養液注入装置を現場に設置し て, 毎日一定量を接種する方式が主に採用されている. そのため, 培養液中の微生物の長期間の生存性の維持 が品質管理の上で特に重要となる。杉森ら ${ }^{3}$ は, 開発 した油脂分解菌が保存中に急速に死滅したと報告して いる. そこでAeromonas sp. KHU 株を現場適用するた めの基礎試験として, 培養と保存を兼用する液体培地 の組成および生存性について検討した.

PYG 培地，PY 培地およびそれらを 2 倍，5 倍希釈し た液体培地を用いて Aeromonas sp．KHU 株の培養およ び生存性を検討した結果（図 1), PYG 培地およびその 2 倍ないし 5 倍希橎培地では, 当初 $10^{8} \mathrm{CFU} / \mathrm{m}$ l の菌数 が 1 日後に $10^{10} \mathrm{cFU} / \mathrm{m} \ell$ に増殖したが，いずれの濃度 の培地においても 7 日間で $10^{2}$ ないし $10^{6} \mathrm{CFU} / \mathrm{ml}$ まで 急激に低下し, その後も徐々に減少した. 7 日間以降 では, いずれの培養液も pH5.0 以下であり, 酸性化が 認められた。一方 PY 培地では, 初発の $10^{8} \mathrm{CFU} / \mathrm{m} \ell$ か ら $1 \sim 2$ 日で $10^{10} \mathrm{CFU} / \mathrm{m} \ell$ 一増殖し, その後 7 日間で約 $10^{8} \mathrm{CFU} / \mathrm{m} \ell$ にまで低下したが，いずれの濃度の培地に おいても, その後もこの菌濃度を維持し，5 倍希釈 PY 培地が最も良好な結果を示した。このとき, PYG 培地 とは対照的に $\mathrm{pH} 8.5$ 程度のアルカリ性であった。これ らの結果から, PYG 培地では, 培地に含まれるグルコ 一スを本菌が資化し，有機酸を蓄積したことにより $\mathrm{pH}$ が著しく低下したため, 菌数が激减したと考えられる.
表 2 Aeromonas sp. KHU の性状および類縁菌との鑑別性状

\begin{tabular}{|c|c|c|}
\hline 性 状 & $\begin{array}{c}\text { Aeromonas } \\
\text { sp. KHU }\end{array}$ & A. hydrophila \\
\hline グラム染色性 & - & - \\
\hline 細胞形態 & 短桿菌 & 短桿菌 \\
\hline カタラーゼ & + & + \\
\hline オキシダーゼ & + & + \\
\hline 運動性 & + & + \\
\hline 硝酸還元 & + & + \\
\hline インドール産生 & - & + \\
\hline ブドウ糖発酵性 & + & + \\
\hline ウレアーゼ & - & - \\
\hline$\beta$-グルコシダーゼ & + & + \\
\hline プロテアーゼ & + & + \\
\hline$\beta$-ガラクトシダーゼ & + & + \\
\hline グルコース利用性 & + & + \\
\hline L-アラビノース利用性 & + & + \\
\hline D-マンノース利用性 & - & + \\
\hline D-マンニット利用性 & + & + \\
\hline マルトース利用性 & + & + \\
\hline クエン酸利用性 & + & + \\
\hline アルギニンデヒドロラーゼ & - & + \\
\hline アセトイン産生（VPtest） & - & + \\
\hline 硫化水素産生 & - & + \\
\hline インドール産生 & - & + \\
\hline DNA 分解酵素 & - & + \\
\hline$\beta$-溶血毒素 & - & + \\
\hline
\end{tabular}

本菌が増殖可能な $\mathrm{pH}$ の範囲は $\mathrm{pH} 5.5 \sim 8.5$ であり（デ 一タ示さず), 両培地における生存性の差異には, 培養 液中の $\mathrm{pH}$ の変動が大きく影響したと推察される.以上 の結果から, 最も高い菌濃度を維持した 5 倍希釈 PY 培地を本菌の培養および保存に適した培地と判断した。

次に，実用レベルの保存性を検証するため，5倍希 釈 $\mathrm{PY}$ 培地 1.8 l に本菌を接種し, $30^{\circ} \mathrm{C}$ で 35 日間静置培 養し，培養法および䖝光染色法を用いて菌数を測定し た（図 2)。平板培養法では，初発の菌濃度 $10^{6} \mathrm{CFU} / \mathrm{m} l$ から 1 日後に $10^{7} \mathrm{CFU} / \mathrm{m} \ell$ のレベルに増加し, その後の 約 3 週間は多少の増減はあるものの $10^{7} \mathrm{CFU} / \mathrm{m} \ell$ 前後の 值を示し, その後, $10^{6} \mathrm{CFU} / \mathrm{ml}$ に低下した. 一方, CTC-SG I 二重染色法による菌濃度は，平板法と似たパターン を示したが, そのレベルは $10^{8} \mathrm{CFU} / \mathrm{m}$ で, 平板法の 3.0 〜59 倍高かった. 自然界の細菌の多くは培養できない 


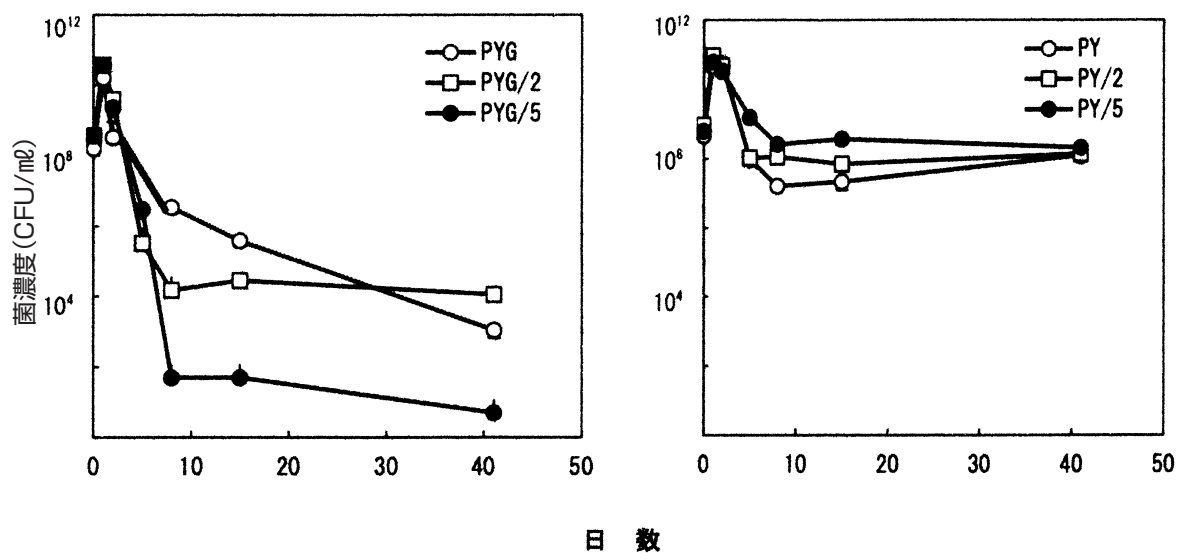

図 1 Aeromonas sp. KHU の保存性に及ぼす培地の影響

PYG 培地，PY 培地およびそれぞれを 2 倍および 5 倍希釈した液体培地に本菌の新鮮培養液を $1 / 100$ 量接種し， $30^{\circ} \mathrm{C}$ で 24 時間振とう培養した後, そのまま $30^{\circ} \mathrm{C} て ゙ ~ 41$ 日間静置培養した.

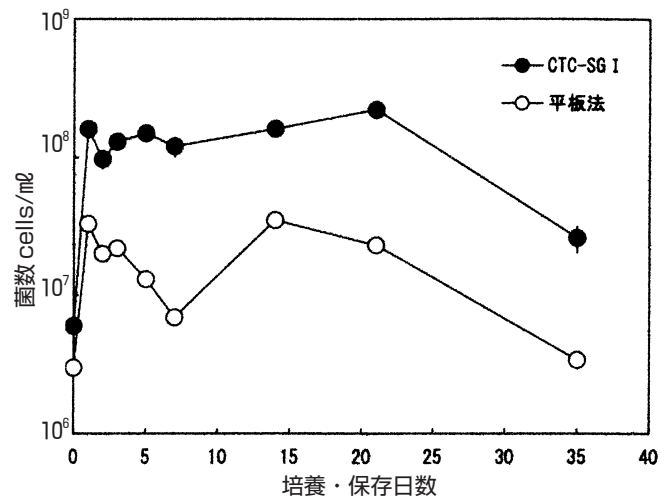

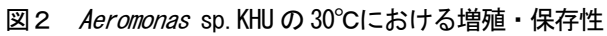
5 倍希釈 PY 培地 1.8 にに本菌を 2 m接種し, $30^{\circ} \mathrm{C}$ で 2 日間静置培養

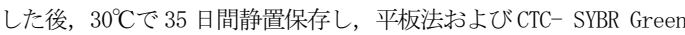
I 二重蛍光染色法により菌数を測定した.

状態にあることはよく知られているが ${ }^{13)}$, 上記の結果 は培養可能な細菌の新鮮培養菌においても, 培養法で は正確な菌数が測定できていない場合があることを示 すものと考えられる.また, 製品管理を行ううえでは, 菌数を迅速に定量することが重要であるが，培養法で は測定に約 1〜2 日間を費やすが, CTC-SG I 二重染色法 では約 5 時間で済み，製品管理にはより適していると 考えられる.

以上の結果により，5 倍希釈 PY 液体培地中において $30^{\circ} \mathrm{C}$ で Aeromonas sp. KHU 株を 21 日間にわたり高濃度 で安定して保存する方法を確立した．現場への適用に おいて, 培養液中の微生物の長期間の生存性の維持が 品質管理の上で特に重要となると考えられるが，微生
物資材の保存および安定性に関する報告は極めて限ら れている．杉森ら ${ }^{3)}$ は，開発した油脂分解菌の保存中 における生存性について検討し，凍結乾燥菌体でも， 保存 30 日後の生存率は $25^{\circ} \mathrm{C}$ では $15 \% ， 40^{\circ} \mathrm{C}$ では $4 \%$ であり，長期間の保存には，さらなる製剤化方法の検 討が必要としている．本研究で示されたように，培地 の種類によっては，培養には適していても，保存には 適さない場合もあり，製品開発および管理において， 保存性を十分検討することが重要である.

\section{3 Aeromonas sp. KHU 株の油脂分解試験}

Aeromonas sp. KHU 株の油脂分解力をサラダ油培地を 用いた振とう培養により検定した。 その結果（図 3), 油脂分（n一へキサン抽出物）は初発濃度約 $4,000 \mathrm{mg} / \mathrm{l}$ から 48 時間後には約 $2,500 \mathrm{mg} / \mathrm{l}$ に減少し， $38 \%$ が分 解した。このときの油脂分解速度は $32.2 \mathrm{mg} / \mathrm{l} / \mathrm{h}$ と算

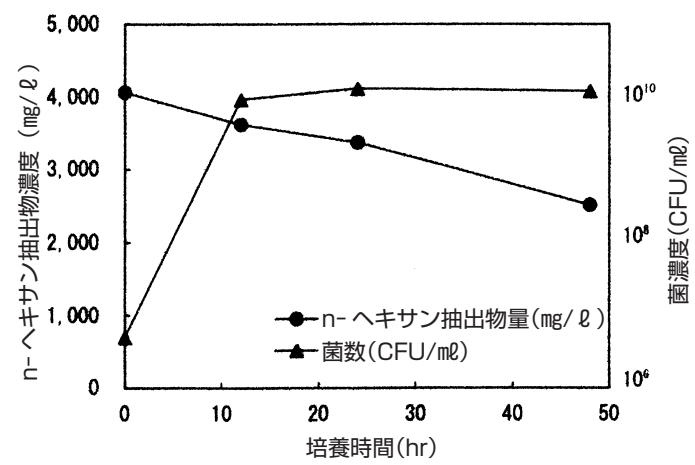

図 3 サラダ油培地における Aeromonas sp. KHU の油脂分解 および増殖

普通ブイヨン $100 \mathrm{~m} l$ に市販サラダ油を $5 \mathrm{~m} / /$ l添加し, 本菌新 鮮培養液 $1 \mathrm{~m} \ell$ を接種し, $30^{\circ} \mathrm{C}$, で 48 時間振とう培養した. 
定された。一方, 本菌の菌濃度は, 初発の $5.0 \times 10^{6}$ $\mathrm{CFU} / \mathrm{ml}$ から 12 時間後には $1.2 \times 10^{10} \mathrm{CFU} / \mathrm{ml}$ に増加し, その後, 48 時間後までほぼ一定の高い菌濃度を維持し た. 本菌の比増殖速度は 12 時間までの増殖曲線から $0.63 / \mathrm{hr}$ （平均世代時間 1.1 時間）と算定される. これ らの結果より, 本菌は, 植物油を好気的に分解して増 殖することが確認された。 また，本菌が定常期に達し た後も油脂分解が持続しているが，これは菌体外に分 泌された油脂分解酵素の働きによるものであると考え られる。

厨房排水を用いた本菌による油脂分解試験の結果を 図 4 に示す．この場合, 現場グリストラップへの菌接 種量と同程度の $1 / 1,000$ 量を接種した. 低濃度の油脂 含有厨房排水では (図 4A), 初発の油脂濃度約 $330 \mathrm{mg} / \mathrm{l}$ から直線的に減少し，15 時間後には約 $30 \mathrm{mg} / \ell$ に減少 した. このときの油脂分解速度は, $20 \mathrm{mg} / \mathrm{l} / \mathrm{hr}$ と算定 された.一方，未接種（曝気のみ）の場合， 5 時間ま では接種区と同様に油脂分は減少したが, その後, 減 少速度が低下した. 本菌無接種区では 15 時間で油脂分 解率は $39 \%$ であったのに対し, 接種区では $91 \%$ で, 分 解率が $52 \%$ 高まった. 一方, 高濃度油脂含有厨房排水 では (図 4B), 初発の油脂濃度 $2,500 \mathrm{mg} / \mathrm{l}$ に対して, 無接種区においては 24 時間で油脂分解率が $38 \%, 48$ 時間で $61 \%$ であった。一方，接種区では，24 時間で $46 \%, 48$ 時間で $86 \%$ の油脂分解がみられ, 無接種と比 べ分解率が $25 \%$ 高まった. このとき, 油脂分解速度は 約 $46 \mathrm{mg} / \mathrm{l} / \mathrm{hr}$ と算定された.

上記の結果は，厨房排水中の油脂は，曝気すること
で常在菌により多少分解すること, Aeromonas sp. KHU 株の接種により分解が促進されたこと，および排水中 の油脂濃度の高低にかかわらず，本菌は高い分解能力 を発揮することが判明した。

\section{4 Aeromonas sp. KHU 株によるグリストラップ内油 脂分解試験}

Aeromonas sp. KHU 株を現場のグリストラップに適用 し，その浄化効果を検証した（図 5)。まず，最初の 37 日間は曝気処理のみとし，14 日間おきに業者による清 掃を行った。油脂分は測定開始時に $155 \mathrm{mg} / \mathrm{l}$ で，その 後, 徐々に増加し約 $220 \mathrm{mg} / \mathrm{l}$ となり, 清掃によりいっ たん減少したが，その後再び増加するというパターン を繰り返した。しかし，本菌の毎夜接種開始後は 7 日 間で $40 \mathrm{mg} / \mathrm{l}$ 以下の值となり, その後も 35 日後まで同 様の值を推移した。 $\mathrm{pH}$ は, 当初 $\mathrm{pH} 4$ 台の酸性を示した が，本菌接種後から徐々に上昇し，35 日後には $\mathrm{pH} 7$ に 達した. この $\mathrm{pH}$ の上昇は, 排水中に当初有機酸が蓄積 されていたものが，本菌接種により好気的分解が促進 され，有機酸が消費されたためと推察される.

以上のように，本実地試験により，グリストラップ 内の油脂分解において, 本菌接種の効果が実証された. グリストラップの現場適用試験に関しては，報告が少 ない. 現場での数日間 ${ }^{1)}$ または 1 週間程度 ${ }^{3)}$ の試験成 績に関しては報告があるが，菌接種前後の数ヶ月間に わたる現場試験は，著者らが知る限りでは本研究が初 めてである.

試験したグリストラップの実容積は 300 lであり, ここに $250 \mathrm{mg} / \ell$ の油脂分が蓄積していたと仮定すると,
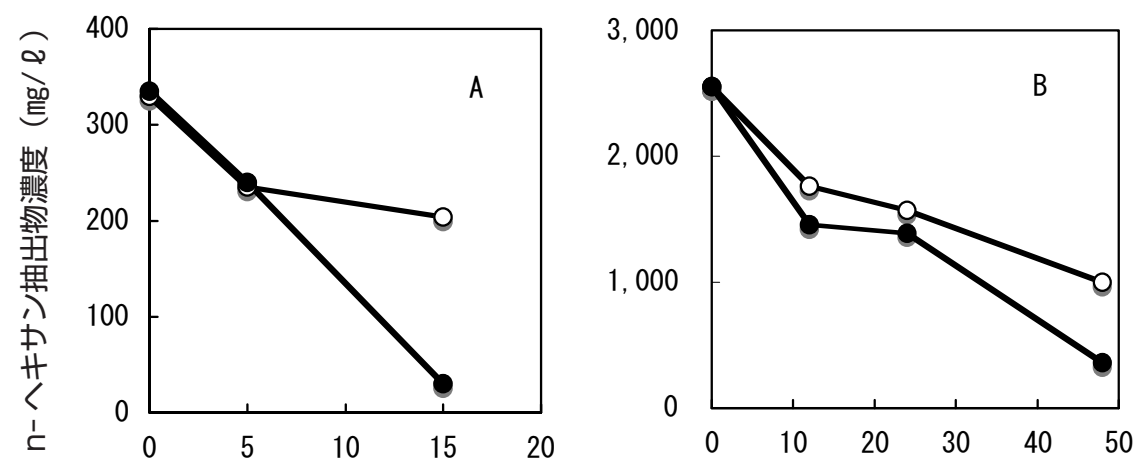

曝気時間 (hr)

図 4 Aeromonas sp. KHU による厨房排水中の油脂分解

- - 曝気のみ, 一- 曝気 + Aeromonas sp. KHU

厨房排水 1 lに本菌の新鮮培養液を $1 \mathrm{ml}$ 接種し, $30^{\circ} \mathrm{C}$ で通気培養した. 


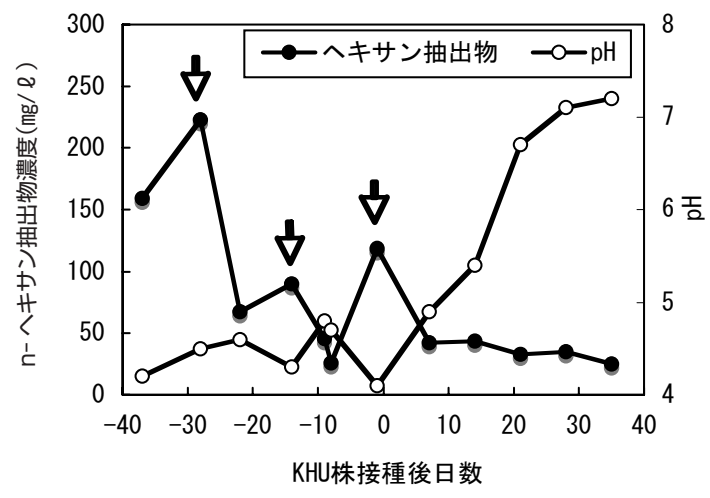

図5 Aeromonas sp. KHUの現場グリストラップにおける油脂分 解効果

矢印は業者による清掃を示す.

最初の 37 日間は曝気処理のみとし, その後, 本菌を毎晚 21 時に 100 $\mathrm{m} \ell$ 接種し，これを 35 日間続け, 油脂分濃度および $\mathrm{pH}$ を測定した.

本菌を夜間接種することにより，菌数は比増殖速度を 0.63/hr とすると $10^{6} \mathrm{CFU} / \mathrm{m} \ell$ から一晚（12 時間）で $10^{9} \mathrm{CFU} / \mathrm{m} \ell$ となり, 油脂分解速度を $20 \mathrm{mg} / \mathrm{l} / \mathrm{hr}$ とす ると $240 \mathrm{mg} / \mathrm{l}$ の分解となり, 油脂分が規制值 $30 \mathrm{mg} / \mathrm{l}$ 以下に低下し, グリストラップ全体では $72 \mathrm{~g}$ の油脂分 が分解されたと算定される. 図 5 の結果はこの見積も りを裏付けるものである。，一方，日中の場合，大量に 厨房排水が出る. $300 \mathrm{l}$ のグリストラップに 1 日約 $8 \mathrm{~m}^{3}$ の厨房排水が流入し, 食堂稼働時間が 12 時間であるの で, 厨房排水のグリストラップ内滞留時間は約 30 分〜

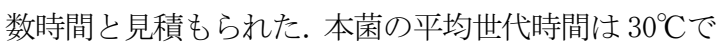
約 1.1 時間であるため, グリストラップの排水滞留時 間が 1 時間未満となる場合, 寸なわち日中の繁忙時間 帯には, 本菌は wash-out されることになる.このため, 現場では毎晚の菌接種が必要となる。また，グリスト ラップで油脂分を安定して微生物的に分解するために は，排水滞留時間を十分確保することが重要であり， グリストラップが現状より大きな容積をとることが望 まれる．また，水量の多い時間帯には，曝気を停止し てグリス分が下水に流出することを抑制するとともに トラップ内に蓄積させ, 夜間に曝気処理することで分 解を促進するという方法も実用化されている ${ }^{11}$.

井星ら ${ }^{1)}$ は，複合菌とリパーゼの併用により，150 $\mathrm{mg} / \ell$ のオリーブオイルが 6 時間で約 $90 \%$ 分解し, 厨房 排水中の 1,100 および $5,800 \mathrm{mg} / \mathrm{l}$ の油脂分が 24 時間 で,それぞれ $86 \%$ および $91 \%$ 分解したと報告している. これらの值から油脂分解速度は 25〜220 mg/l/hr と算 定される。また, 杉森ら ${ }^{3)}$ は, 油脂分解菌
(Acinetobacter sp. ) )゙厨房排水中の 114 および 260 $\mathrm{mg} / \mathrm{l}$ の油脂分が 24 時間でそれぞれ 96 および $90 \%$ 分解 し， $3,000 \mathrm{mg} / \ell$ のサラダオイルが 24 時間で $83 \%$ 分解 したと報告している。これらは油脂分解速度として, それぞれ 4.6, 9.7 および $103 \mathrm{mg} / \mathrm{l} / \mathrm{hr}$ と算定される. 本菌の油脂分解能力はグリストラップ油脂分で 20〜 $46 \mathrm{mg} / \mathrm{l} / \mathrm{hr}$, サラダ油で $32 \mathrm{mg} / \mathrm{l} / \mathrm{hr}$ であった. 寸なわ ち本菌は, 比較的低濃度の油脂分においては，上記の 先行研究における油脂分解菌と同等かそれ以上の分解 能力を有寸ると考えられるが, 数千 $\mathrm{mg} / \mathrm{l}$ を超える高濃 度の油脂分においては，やや分解能力が低い傾向があ る. 一方, 現場試験では優良な油脂分解を示しており

（図 5)，これは, 油脂分の負荷が数百 $\mathrm{mg} / \mathrm{l}$ と比較的低 かったためと考えられる.

\section{3. 結 論}

本研究では, 油脂分解能およびタンパク質分解能の 強い細菌を欴房排水から新規に分離・選抜し，厨房排 水の浄化に有効であるか実験室試験および現場グリス トラップ試験により検証した。本研究で得られた知見 は以下の通りである.

1）11 点の㕑房排水から新規に油脂分解菌の分離を行 い, 311 株の分離細菌株から油脂分解能, タンパク 質分解能およびデンプン分解能の高い分離株 Aeromonas sp. KHU を選抜し，環境中で使用するこ とを考慮し，非病原性であることを確認した。

2）培養および保存性に適した培地として 5 倍希釈 PY 培地を選定し, 同時に, CTC-SG I 二重染色法を菌 数測定に用いることで，製品管理に有効な迅速定 量法を確立した。細菌を用いたグリストラップ中 の厨房排水処理において，培養および保存性に適 した培地の選択・検証が最も重要なステップであ るといえる.

3）油脂分解性を実験室および現場で測定した結果, 厨房排水中の油脂分濃度の高低にかかわらず高い 分解率を示した. しかし, 本菌の増殖速度よりも 滞留時間が短い時間帯もあるため, 現場では毎晚 の菌接種が必要であり, グリストラップで油脂分 を安定して微生物的に分解寸るためには，排水滞 留時間を十分確保することが重要である.

今後，検討すべき課題もあるが，本菌を用いた自動 接種システムの使用により, グリストラップの清掃作 業が大幅に軽減されることが期待される. 
Corresponding author: 染谷 孝

E-mail : someyat@cc.saga-u. ac.jp

\section{文献}

1）井星郁夫，中西康雄;廃棄物処理・再資源化技術, 122-127 シー エムシー出版, 1999.

2）加藤明徳, 岡庭良安, 奥田慎一; リパーゼ生産細菌を用いた油 脂含有排水処理，用水之廃水，37, 303-307, 1995.

3）杉森大助, 中村正寿ら; 油脂分解微生物製剂による油脂含有排 水処理，生物工学会誌，80，559-562，2002.

4) Yoshiki Matsumiya, Daisuke Wakita et al. ; Isolation and characterization of lipid-degrading bacteria and its application to lipid-containing wastewater treatment, J. Biosci. Bioeng., 103, 325-330, 2007.

5) Shin-ichi Okuda, Kazutoshi Ito, Hiroko Ozawa and Kazuo Izaki; Treatment of 1 ipid-containing wastewater using bacteria which assimilate 1ipid, J. Ferment. Bioeng., 71, 424-429, 1991.

6) 染谷孝; 堆肥化促進微生物資材の動向と評価 ～蛍光染色法な どによる評価，肥料土つくり資材大辞典，1031-1041, 農文教, 2007.

7) Sierra, G. ; Simple method for the detection of lipolytic activity of microorganisms and some observations on the influence of the contact between cells and fatty substrates. Antonie van Leeuwenhoek, 23, 15-22, 1956.
8 ) Martley, F. G., Jayashankar, S. R and Lawrence, R. C. ; An improved agar medium for the detection of proteolytic organisms in total bacterial counts. J. Appl. Bact., 33, 363-370, 1970.

9）コーワン， S. T. : 医学細菌同定の手引き，坂崎利一訳，335，近 代出版, 1979 .

10) Grace C.Y. Wang and Yue Wang ; Frequency of Formation of Chimeric Molecules as a Consequence of PCR Coamplification of $16 \mathrm{~S}$ rRNA Genes from Mixed Bacterial Genomes, Appl. Environ. Microbiol., 63, 4645-4650, 1997.

11) Naoko Yoshida and Akira Hiraishi ; An improved redox dye-staining method using 5-cyano-2, 3-ditolyl tetrazolium chloride for detection of metabolically active bacteria in activated sludge, Microbes Environ., 19, 61-70, 2004.

12 ) Izard, Gavini, Trinel and Leclerc ; Validation of the publication of new names and new combinations previously effectively published outside the IJSB; List No. 7 In Bergey' s Manual of Systematic Bacteriology, Springer, Vol. II, Part B, Springer-Verlag, NY. 759-763, 2005.

13）染谷 孝, 犬伏和之，山本啓之，加藤憲二; 土壌・水圈におけ る Viable but nonculturable (VBNC) 微生物の解析手法の進歩 と課題, 土と微生物, 53, 45-51, 1999.

\title{
Application of a Lipolytic Bacterium to Wastewater Treatment of Cooking Grease Traps
}

\author{
Noriko RYUDA*, Kanari YOKOBORI*, Aya INOUE*, Kenji ANNOURA*, Isao TESHIMA** \\ Daisuke UENO*, Koichi INOUE*, Takashi SOMEYA* \\ * Division of Soil Environment, Faculty of Agriculture, Saga University \\ $* *$ Kyushu Chemical Clean Co. Ltd.
}

Lipolytic bacteria were isolated from restaurant grease traps, and the isolate KHU, which has strong lipolytic activity, was selected for kitchen wastewater treatment. The isolate KHU, which was identified as Aeromonas sp., also has proteolytic and amilolytic ability and no pathogenic characteristics. It consumed grease and oil in restaurant wastewater at a rate of 20-46 mg/ $/ \mathrm{hr}$. An apparatus (the Oil Control System) which aerates a grease trap continuously and inoculates the culture of the bacterium once a day automatically into a grease trap was developed and tested. The system reduced grease and oil concentration in drainage water by $95 \%$ or greater and kept total grease quantity at $40 \mathrm{mg} / \ell$ or less during five weeks of the experiment.

Key Words : lipolytic bacteria, Aeromonas, grease trap, kitchen wastewater treatment 